\author{
Agnieszka Anna Niekrewicz \\ Państwa Wyższa Szkoła Zawodowa im. Jakuba z Paradyża \\ w Gorzowie Wielkopolskim
}

\title{
Środki językowo-obrazowe służące etykietowaniu polityków w memach internetowych
}

Mem internetowy najczęściej definiowany jest jako 'kompleks znaków werbalnych i wizualnych, przekazywany i modyfikowany za pośrednictwem sieci' [Kamińska 2011: 61; Niekrewicz 2015: 13-20]. Typowy mem ma formę rysunku lub fotografii, zazwyczaj opatrzonych żartobliwym podpisem. Nastawienie na zabawę słowem i obrazem nie wyklucza traktowania memów jako głosów w publicznej dyskusji. W tym ujęciu humorystyczne obrazki stają się środkiem służącym krytyce społeczno-politycznej, formułowaniu diagnoz współczesnych problemów i wyrażaniu refleksji na temat życia politycznego. Memy mogą zarówno stanowić autonomiczne wypowiedzi w dyspucie, jak i być uzupełnieniem głosów wyrażonych werbalnie. Ich funkcja w dyskusji jest niejednolita: inicjują spór, są argumentami lub kontrargumentami, ilustrują tezy, podsumowują, formułują wnioski, rozładowują napięcie, pozwalają na zmianę tematu etc.

Memy najpopularniejsze - tzn. najczęściej kopiowane, przetwarzane i komentowane - są publikowane przez portale informacyjne oraz internetowe wydania gazet i czasopism jako głos zwykłych obywateli w dyskursie społeczno-politycznym. Posłużenie się memami pozwala pokazać nastroje społeczne, zastępuje sondę lub badanie ankietowe, a jednocześnie umożliwia ostrą, niekoniecznie merytoryczną krytykę, niezgodną z wymogami dziennikarskiego obiektywizmu, ale usprawiedliwioną cytowaniem cudzych opinii. Można przypuszczać, że dla niektórych redakcji czynnikiem decydującym o publikacji jest dosadność języka i otwartość w wyrażaniu poglądów, które w obliczu obowiązującej politycznej poprawności mogą stanowić sposób na obejście zasad.

Coraz częściej pojawiają się w mediach opinie negujące spontaniczny charakter procesu dystrybucji memów politycznych [Kosedowski 2015]. 
Tezy zakładające tworzenie żartobliwych obrazków na zamówienie sztabów wyborczych pozostają nieudowodnione, ale zasiewają ziarno wątpliwości w dotychczasowych teoriach opartych na koncepcji rozprzestrzeniania się memów dzięki sile ,zaraźliwości” [Conte 2000: 83-120; Kamińska 2011: 61; Walkiewicz 2012: 51]. Memów tworzonych na zamówienie i popularyzowanych przez opłaconych internautów w sieciach społecznościowych nie można by zatem uznać za głosy obywatelskie w dyskursie publicznym. Jednak nawet jeżeli odrzuci się tezę o wyrażaniu przez memy nastrojów dominujących w społeczeństwie, to ich siła oddziaływania na nastroje społeczne pozostaje niezaprzeczalna. Dowodem na to jest choćby klęska w wyborach prezydenckich i parlamentarnych w 2015 roku partii najczęściej i najostrzej krytykowanej w memach internetowych. Zwycięstwo w wojnie na memy - bez względu na to, z czyjej inicjatywy była prowadzona - przełożyło się na realny sukces polityczny.

Niezależnie zatem od sposobu rozstrzygnięcia kwestii autorstwa i dystrybucji memów warto przyjrzeć się technikom kreowania negatywnego wizerunku partii i ich przedstawicieli w memach internetowych. Celem artykułu jest wskazanie środków językowych służących deprecjonowaniu poszczególnych polityków i zarazem przyczyniających się do utrwalania ich jednoznacznego aksjologicznie wizerunku, zazwyczaj opartego na jednej wyolbrzymionej cesze.

Hiperbolizowane wady przypisuje się politykom na podstawie rzeczywistej sytuacji, która dzięki medialnemu rozgłosowi stała się jednostką informacji o cechach memetycznych, czyli wielokrotnie kopiowaną i modyfikowaną w sposób nie zawsze zgodny z istotą pierwowzoru. Cechy tego rodzaju tworzą memetyczne stereotypy, implikują sposób przedstawienia poszczególnych polityków, zarówno w zakresie treści, jak i formy językowej. W ten sposób przekonują kolejnych internautów tworzących memy do poszukiwania jedynie nowych uzasadnień apriorycznych sądów. Memy tego rodzaju stanowią rodzaj wypowiedzi zamkniętej na inne racje i argumenty. Sporadycznie skłaniają osoby popierające danego polityka do repliki, natomiast znacznie częściej zachęcają tylko do modyfikacji formy wypowiedzi, przy zachowaniu jej intencji. W rezultacie rośnie zbiór memów opartych na tym samym szablonie, podtrzymujących ten sam negatywny stereotyp. Szablony memetyczne można uznać za modele służące potwierdzeniu wartościujących etykietek nadawanych osobom publicznym oraz reprezentantom różnych środowisk.

Zatem dla przykładu: Aleksandrowi Kwaśniewskiemu przypisuje się pijaństwo, Hannie Gronkiewicz-Waltz - skąpstwo, Antoniemu Macierewiczowi - mitomanię graniczącą z szaleństwem, Jarosławowi Kaczyńskiemu starokawalerskie dziwactwa i nienawiść do Donalda Tuska, Bronisławowi 
Komorowskiemu - nieprzestrzeganie zasad ortografii rozszerzone na ignorancję w wielu innych zakresach, Andrzejowi Dudzie - bezgraniczne podporządkowanie prezesowi partii, Donaldowi Tuskowi - cynizm, Krystynie Pawłowicz - nietolerancję połączoną z agresją, Januszowi Korwin-Mikkemu nienawiść do lewicy, Lechowi Wałęsie - hedonistyczne korzystanie z życia, Barakowi Obamie - brak wiedzy o świecie istniejącym poza granicami Ameryki, Władimirowi Putinowi - despotyzm ukrywany za maską mistrzowskiej propagandy.

W memach realizujących ten sam szablon memetyczny można wyróżnić powtarzające się środki językowe służące uwydatnieniu danej cechy. Wynika to $\mathrm{z}$ charakteru samego szablonu, który określa zarówno treść, jak i formę wypowiedzi tworzącej mem.

\section{Zmiany pisowni}

Zapisywanie wyrazów niezgodnie z zasadami jest w memach internetowych często stosowanym środkiem o różnorodnych funkcjach: deprecjonującej, ludycznej, semantycznej [Niekrewicz 2015: 61-78]. Społecznościowa akceptacja braku poprawności memetycznej pisowni, wytworzona za sprawą globalnej popularności lolkotów ${ }^{1}$ [Niekrewicz 2013: 157-169] i ich niezgodnego z normą języka, przyczynia się do ogromnego zróżnicowania sposobów naruszania w memach zasad grafii. Powszechne jest stosowanie zapisu fonetycznego zapożyczeń i wyrazów rodzimych, zamiana właściwych znaków na inne, brak polskich znaków diakrytycznych, łączenie liter $\mathrm{z}$ ideogramami w obrębie jednego wyrazu, skracanie wyrazów i wyrażeń, przestawianie znaków, niewłaściwa pisownia łączna lub rozdzielna.

Wszystkie wymienione typy naruszenia zasad pisowni są wykorzystywane w tworzeniu negatywnego wizerunku byłego prezydenta Bronisława Komorowskiego, który od czasu ujawnienia przez media błędu ortograficznego we wpisie do księgi kondolencyjnej ambasady Japonii funkcjonuje w sieci jako uosobienie dysortografika. Znaczącą rolę w kształtowaniu takiego wizerunku prezydenta Komorowskiego odegrało powstanie szablonów memetycznych „Komorofzki” i „Mściwy Bronisuaf”. Przejście od nagłośnionego w mediach wydarzenia do ukształtowania na jego podstawie negatywnej etykietki, która tworzy jednostronny, schematyczny wizerunek postaci, jest przykładem charakterystycznej dla memów nadinterpretacji oraz intensyfikacji. Niepoprawny

1 Lolkot (ang. LOL laughing out loud - pol. 'śmiejąc się głośno' + ang. cat 'kot') - typ memu internetowego, którego bohaterami są koty lub inne zwierzęta ukazywane w sposób skłaniający do antropomorfizacji, posługujące się językiem niepoprawnym pod względem gramatycznym i ortograficznym. 
zapis stał się nieodłączną cechą memetycznych wypowiedzi prezydenta, dezawuującą ich wartość, natomiast autor otrzymał stały przydomek $B u l^{2}$.

Niewłaściwa pisownia przekreśla wartość merytoryczną wypowiedzi, odwraca uwagę od treści i ośmiesza ich nadawcę. Należy jednak podkreślić, że niepoprawnie zapisane wypowiedzi Bronisława Komorowskiego są dodatkowo konstruowane tak, by wykazać ich absurdalność, ignorancję nadawcy oraz lekceważenie wyborców, np. Morze i robię błendy ale zarabiam wiencej w miesionc nisz ty w caty rok; Morzna zaprosić OBWE? Nie morzna!; Sondze. Rze ACTA zrobi z Fami pożontek; Donald pomusz bo sie buntujom; To odmenty szalęństwa? Panowie, policzmy głosy! Te głosy mószo być skótecznie i óćciwie policzone!; Jak obiecam wam referendóm, JOW-y i grószki na wieżbie to wygram drógom tóre wyboruf.

Modyfikacje zapisu w przypadku memów z wizerunkiem Bronisława Komorowskiego mają nie tylko świadczyć o nieznajomości ortografii, ale także odzwierciedlać niepoprawną wymowę - nadmierne uproszczenia grup spółgłoskowych, niewyraźną wymowę spółgłosek półotwartych oraz niewłaściwą artykulację samogłosek nosowych i zapożyczeń. Zabiegi te ilustrują memetyczną tendencję do rozszerzania zarzutów i formułowania krytyki niepopartej argumentami.

Wskazana tendencja nie oznacza całkowitej rezygnacji z realizmu w przedstawianiu znanych postaci. Twórcy memów oddają przede wszystkim specyficzną wymowę spółgłoski „r”, zastępując ją przez „h”, „l”, „,” oraz „u”, np. Z ptezesa Jatostawa to taki Zollo jak ze mnie Lobin Hood (Hanna Gronkiewicz-Waltz); Dhuga linia metha? Zalana, jak Kopacz w Behlinie (Hanna Gronkiewicz-Waltz); Vat na żauty z puemieua (Donald Tusk); Gowin będzie plemietem (Donald Tusk).

Wypowiedzi Lecha Wałęsy są zapisywane tak, by odzwierciedlić niewłaściwą artykulację samogłosek nosowych. Internauci czynią to jednak dość niekonsekwentnie, w rezultacie przypisują byłemu prezydentowi różne typy błędów, np. Nie o takom Polskie walczyłem; Nie o takie Polskie walczyłem; Nie o take Polske walczyłem; Nobla już mam. Teraz chcem jeszcze oskara.

Zamiana pojedynczych znaków, mogąca sprawiać wrażenie literówki lub typowej dla memów ludycznej innowacji graficznej, często jest w istocie mechanizmem żartu słownego, którego odczytanie wymaga znajomości memetycznej etykietki nadanej politykowi. W memach $\mathrm{z}$ wizerunkiem Donalda Tuska zamiana ta polega na zastąpieniu „w” przez „,

2 Przydomek motywowany treścią niepoprawnego wpisu prezydenta do księgi kondolencyjnej ambasady Japonii: $w$ bulu i nadzieji. W nawiązaniu do utrwalonego przydomka Bronisława Komorowskiego jego przeciwnika politycznego Andrzeja Dudę twórcy memów nazwali środkiem przeciw-bulowym [zob. np. MK 2011]. 
polskich i angielskich zawierających morfem ,wat” lub ang. what. Tym sposobem aktualizowany jest wielokrotnie stawiany w memach zarzut podwyższenia podatków wbrew wcześniejszym obietnicom utrzymania ich na stałym poziomie. Wypowiedzi zapisywane w ten sposób nie muszą odnosić się do tematów politycznych, toteż właściwa ich interpretacja uzależniona jest od rozpoznania memetycznej konwencji, np. If you know vat I mean; Vat are you doing?; Wszystkim jubilatom życzę sto vat; Jak nazywa się ulubiona impreza Donalda? Pryvatka; Mój ulubiony kwiat to błavatek; Wybraliście mnie na vatażkę waszego narodu; Ładny mam kravat?.

\section{Powtórzenia}

Każdemu człowiekowi zdarza się sformułować niefortunną wypowiedź, o której chciałby jak najszybciej zapomnieć. Tymczasem od momentu pojawienia się memów internetowych niewielkie są szanse na puszczenie w niepamięć niezręcznych wypowiedzi polityków. Twórcy memów przypominają je wielokrotnie, cytując dosłownie lub parafrazując, umieszczając pod wizerunkiem ich autora lub jego politycznych popleczników albo dokonując ich całkowitej dekontekstualizacji. Niezależnie od zabiegu dokonanego na danej frazie, zostaje ona utrwalona $\mathrm{w}$ pamięci odbiorców, na zawsze skojarzona $\mathrm{z}$ danym politykiem, przez co przyczynia się do utrwalenia jednostronnego, negatywnego wizerunku. Internauci bowiem szczególnie chętnie sięgają po wypowiedzi demaskujące cechy i poglądy, które nie przysparzają politykom chwały, zwłaszcza łamiące normy językowe, stylistyczne lub obyczajowe.

Cytaty o genezie politycznej, mające największą frekwencję w memach funkcjonujących w sieci w roku 2015, to: Sorry, taki mamy klimat ${ }^{3}$; To chuj, dupa i kamieni kupa ${ }^{4}$; Państwo polskie istnieje tylko teoretycznie ${ }^{5}$; Zrobiliśmy laske Amerykanom ${ }^{6}$; Łacze się w bulu i nadzieji ${ }^{7}$; Nie przekonają nas, że białe jest białe, a czarne jest czarne ${ }^{8}$.

3 Komentarz minister Elżbiety Bieńkowskiej w programie TVN „Fakty po faktach”, odnoszący się do przyczyny opóźnień pociągów w czasie śnieżyc i mrozu [zob. Bieńkowska o klopotach... 2014].

4 Wypowiedź ministra Bartłomieja Sienkiewicza w rozmowie ujawnionej przez „Wprost” [Latkowski, Majewski, Bielakowski i in. 2014].

5 Zob. przyp. 4.

6 Wypowiedź ministra Radosława Sikorskiego w rozmowie ujawnionej przez „Wprost” [Latkowski, Majewski, Bielakowski i in. 2014: 14-24].

7 Wpis prezydenta Bronisława Komorowskiego do księgi kondolencyjnej [Wpis prezydenta Bronistawa... 2015].

8 Słowa Jarosława Kaczyńskiego w exposé wygłoszonym 19 lipca 2006 roku [,,Nas nie przekonaja... 2015]. 
Umocnieniu wizerunku polityka może służyć także powtarzanie słów kluczy, które poprzez utrwalenie w memetycznych wypowiedziach na jego temat przywołują treść niewyrażoną wprost, ale dla odbiorców memów jednoznaczną. Pod fotografiami Aleksandra Kwaśniewskiego są zatem umieszczane słowa piateczek i procent, które mają utrwalić wizerunek byłego prezydenta jako osoby ceniącej zabawę i alkohol. Wyraz ból/bul nie tylko jest wplatany do wypowiedzi przypisywanych Bronisławowi Komorowskiemu, ale także pełni funkcję przydomka powtarzanego m.in. w memach z Andrzejem Dudą, którego działanie przeciwbulowe [!] podkreślano wielokrotnie w trakcie prezydenckiej kampanii wyborczej. Wyrażeniem powtarzanym w memach opartych na szablonie „Napuszony Jarosław” do niedawna była wina Tuska. Po zmianach na scenie politycznej słowo wina pozostało kluczem do memetycznej charakterystyki Jarosława Kaczyńskiego, uwydatniającym stosowany przez niego schemat retoryczny ponoszenia odpowiedzialności przez przeciwników politycznych za wszystkie porażki i trudności. Popularność zyskały wyrażenia wina Kopacz; wina Kopaczotuska; wina Petru; wasza wina.

W memach opartych na wizerunku Janusza Korwin-Mikkego powtarzany jest przymiotnik prawy podkreślający orientację polityczną, np. Myje zęby tylko po prawej stronie; Ma serce po prawej stronie; Ma dwie prawe ręce; Raz, $d w a, p_{a}$ wa... Raz, dwa, prawa ...; Prawy do prawego. Wypij kolego; Podpisuje się tylko z prawej strony. Typowa dla memów skłonność do intensyfikacji sprawia, że powtórzenia tego rodzaju przybierają formę upodobnień leksykalnych, w wyniku których morfem -lew- niezależnie od znaczenia i pisowni (także -lev-) - zostaje zastąpiony przez - praw-. W ten sposób tworzone są neologizmy często pozbawione odrębnego znaczenia, a jedynie podkreślające skrajną, doprowadzoną do absurdu prawicowość przekonań polityka nazywanego zabójca/pogromca lewaków, np. Czeka aż gwiazda polskiej piłki zostanie Prawandowski (zam. Lewandowski); Mógtbym przeczytać Narnię gdyby napisat ja Prawis (zam. Lewis); Do zmiany koła używa prawarka (zam. lewarka); On nie podlewa kwiatków. On je podprawia (zam. podlewa); Będąc w kosmosie prawituje (zam. lewituje); Gdy przechyla szklankę to jego napój się wyprawa (zam. wylewa).

\section{Polisemia i homonimia}

Komizm oparty na wieloznaczności i podobieństwie brzmieniowym wyrazów jest najczęściej wykorzystywanym żartem słownym. Odbiorcę bawi odkrycie nowego znaczenia w wypowiedzi, która pozornie niosła inną treść lub nawet wydawała się pozbawiona sensu. W procesie dekodowania komunikatu odbiorca dostrzega nietrafność pierwszego rozpoznania, co staje się źródłem 
żartu. W memach etykietujących polityków rozpoznanie wtórne wymaga znajomości konwencji. Wyzyskiwana jest bowiem wieloznaczność lub podobieństwo brzmieniowe słów kluczy, które tworzą negatywny wizerunek polityka. Podstawą przeprowadzanej w ten sposób demaskacji nie jest przywoływanie rzeczywistych wypowiedzi i sytuacji, ale jedynie sugerowanie innego znaczenia, które odnosi się do powtarzanych w memach zarzutów. Wydaje się, że nie jest to przykład eufemizacji oskarżeń, ale raczej zabieg uatrakcyjniający przekaz. W rezultacie lekka, żartobliwa forma przyczynia się do powstania „zaraźliwej” jednostki memetycznej”, utrwalającej określony wizerunek polityka także poza siecią.

Liczne przykłady tego typu odnajdujemy w memach, których bohaterem jest były prezydent Aleksander Kwaśniewski. Wykorzystywane polisemantyzmy i homonimy mogą zostać odniesione do alkoholu, chociaż bez znajomości szablonu zostałyby odczytane zupełnie inaczej. W przypadku homonimii całkowita tożsamość brzmieniowa i graficzna nie jest obligatoryjna. Do homonimów częściowych należą również homofony powstałe w wyniku utożsamienia się brzmieniowego odrębnych wyrazów, często przy tym zachowujące odmienną pisownię, a także wyrazy, które stają się homofonami tylko w przypadku niewłaściwej artykulacji jednego z nich. W badaniach nad komizmem językowym uwzględniane są zarówno homonimy całkowite, jak i częściowe [zob. np. Krasowska 2013: 206]. W memach formy homonimiczne zostają odniesione do swoich odpowiedników formalnych o innym znaczeniu za sprawą odpowiedniego wprowadzenia w kontekst wizualny oraz uruchomienia skojarzeń z memetycznym schematem.

Żarty językowe oparte na polisemii lub homonimii pojawiają się w wypowiedziach Aleksandra Kwaśniewskiego dotyczących różnych tematów, np. Wynik debaty Kopacz - Szydto. Obstawiam zero siedem ('wynik rozgrywki' $\neq$ 'popularna pojemność butelki z alkoholem'); A w przysztym roku znajdę druga połówkę ('partnerka' ₹ 'pół litra wódki'); - PiS daje 500 zł na dziecko, ile by Pan dat na ich miejscu? - Jestem pewien, że starczy CZYSTA! ('niepoprawnie wymawiany liczebnik' ₹ 'pot. wódka czysta'); Co pan prezydent robił w urzędzie skarbowym? - Czekatem na pity (wyrażenie przyimkowe „na pity” "na formularze podatkowe' $\neq$ imiesłów ,napity” 'pijany').

Zastosowanie homonimów i polisemów w wypowiedziach przypisywanych najczęściej atakowanym w sieci politykom Platformy Obywatelskiej służy ilustrowaniu zjawiska wykorzystywania przez nich środków językowych do mani-

9 Jednostkę memetyczną rozumiem tu jako 'jednostkę informacji o dużej sile społecznego oddziaływania'. 
pulowania odbiorcami. Użycie form homonimicznych sprawia, że zacierają się granice między opozycyjnymi pojęciami, a w rezultacie wszelkie zarzuty (np. dotyczące dotrzymywania obietnic wyborczych) mogą zostać odparte. Memy tego rodzaju są częścią licznego zbioru memetycznych wypowiedzi o charakterze demaskatorskim, np. Donald Tusk: Chcieliście drogi? Macie drogi chleb, benzyne... (rzeczownik nmos. 1m., M. 'szlak komunikacyjny' drogi $\neq$ przymiotnik m. lp. 'mający wysoką cenę'); Chcę dobra wszystkich ludzi. Mieć dla siebie (rzeczownik n. lp., D. 'wartość moralna' $\neq$ rzeczownik nmos. 1m., B. 'rzeczy i wartości materialne'); Hanna Gronkiewicz-Waltz na tle zalanej ulicy: Warszawiakom dobrze się powodzi (czasownik, 3 os., lp. 'wiedzie się’ $\neq$ rzeczownik ż., lp., D. 'zalanie przez wodę').

\section{Nazwy wartościujące}

Utrwaleniu negatywnego wizerunku polityków służy zastępowanie ich imion i nazwisk opisowo-wartościującymi nazwami o funkcji etykietek. Określenia tego rodzaju funkcjonowały w dyskursie publicznym na długo przed pojawieniem się Internetu [zob. np. Kochan 1994: 86], ale sieciowe memy ożywiły ten środek perswazji. Memetyczne szablony nie są bowiem niczym innym jak modelami służącymi potwierdzeniu etykietek nadawanych zarówno osobom publicznym, jak i reprezentantom poszczególnych zawodów i grup społecznych. Sposób transmisji memów, a zwłaszcza założenie ich przetwarzania przez innych użytkowników sieci, współgra z intencją upowszechnienia deprecjonującej nazwy, znamienną dla nadawcy wypowiedzi etykietującej. Z tego względu w memach powtarzają się liczne określenia o takim charakterze, np. kolesie, klika, sitwa, złodzieje, oszołomy (o wszystkich politykach), POmyleńcy, POlityczna mafia, Partia Obciachu, Partia Obiboków, Profesjonalne Okradanie, Przebiegli Oszuści (o Platformie Obywatelskiej), chytra baba z ratusza, bufetowa, gronkowiec (o Hannie Gronkiewicz-Waltz), stońce Peru, zdrajca Polski (o Donaldzie Tusku), pisior (o zwolenniku PiS-u), lewak, czerwona hołota (o zwolennikach lewicy), pogromca/zabójca lewaków, Korwin król (o Januszu Korwin-Mikkem), budyń, Maliniak (o Andrzeju Dudzie), napuszony Jarosław/ prezes (o Jarosławie Kaczyńskim).

Wartościowanie może odbywać się nie tylko na płaszczyźnie werbalnej, ale także wizualnej. Politycy krytykowani za kłamstwo i niedotrzymywanie obietnic otrzymują długie nosy na wzór Pinokia - bohatera powieści Carla Collodiego (najczęściej Donald Tusk, Władimir Putin, Jarosław Kaczyński). Prezydent Andrzej Duda jest przedstawiany jako marionetka, za której sznureczki pociąga prezes PiS-u, Jarosław Kaczyński. Upodobnienie do bałwanów, osłów, baranów i małp dotyka polityków reprezentujących wszystkie, bez wyjątku, 
opcje polityczne. Z kolei w okresie swoich rządów politycy PO często otrzymywali etykietki złodziei, przestępców i innych reprezentantów siły zła - byli przedstawiani w więziennych pasiakach, z zasłoniętymi oczami, przesłonięci przez więzienne kraty lub upodobnieni do popkulturowych złoczyńców (np. Jokera z filmu Batman, Lorda Vadera z Gwiezdnych wojen). Politycy, którzy w memach są kreowani na działających irracjonalnie szaleńców (Antoni Macierewicz, Jarosław Kaczyński), otrzymują twarze Napoleona, Don Kichote'a lub po prostu są ukazywani z uzyskanym dzięki grafice komputerowej rozwianym włosem i obłędem w oczach.

Część werbalna memów wartościujących za pomocą obrazu, zwykle jednozdaniowa, potwierdza etykietkę nadaną przez obraz. Precyzuje, kim jest obdarzona nią osoba, np. podpis Posiedzenie rządu pod fotografią bałwanków siedzących przy stole; Debata polityków - zdjęcie członków rządu PO z wydłużonymi nosami; Don Kichote z Żoliborza zapowiada zdecydowana walke $z$ wiatrakami - Jarosław Kaczyński na koniu, na tle elektrowni wiatrowych.

$* * *$

Mimo że wśród memow internetowych dominują te o charakterze humorystycznym, wartościowanie w nich zawarte jest bez wyjątku negatywne. Coraz powszechniejsze we współczesnym dyskursie publicznym ignorowanie informacyjnej rzetelności i obiektywizmu skłania autorów memów do absolutyzowania własnej perspektywy i rezygnacji z merytorycznego uzasadniania formułowanej krytyki. Ważniejsze staje się dążenie do akcentowania antagonizmów, powtarzanie treści, powierzchowność ocen, uogólnianie i wyolbrzymianie zarzutów. W retorykę tego typu wpisuje się także memetyczne etykietowanie polityków, rozumiane jako przedstawianie ich w sposób jednostronny i schematyczny z jedną dominująca cechą negatywną.

Trudno wskazać przyczyny, dla których niektóre zdarzenia lub sytuacje stają się wielokrotnie przetwarzanym tematem memów, a inne pozostają przez internautów niezauważone. Niewątpliwie jednak te trafiające na memetyczny warsztat są poddawane hiperbolizacji oraz innego rodzaju swobodnym przeróbkom tworzącym negatywny wizerunek danego polityka. Środki językowe służące utrwaleniu etykiety to powtórzenia lapsusów popełnianych przez polityków i słów kluczy, które charakteryzują ich zgodnie z memetycznym schematem, zastępowanie imion i nazwisk opisowo-wartościującymi nazwami oraz żarty słowne oparte na polisemii i homonimii pozwalającej na sugerowanie dodatkowych znaczeń. Jednym z najbardziej wyrazistych środków deprecjonujących jest w memach politycznych naruszanie zasad pisowni. Różnicowanie 
typów błędów (np. ortograficzne, artykulacyjne, podporządkowane funkcji semantycznej zamiany pojedyncznych znaków) umożliwia odzwierciedlanie cech charakterystycznych dla poszczególnych polityków, a jednocześnie utrwalanie etykietek ignorantów, dysortografików, niewykształconych prostaków lub - w najlepszym razie - osób z wadą wymowy. Etykietkę utrwala także obraz ukazujący polityka w jednoznacznie wartościowanej roli.

Siła oddziaływania memów w świecie zdominowanym przez powierzchowne odczytywanie przekazów staje się coraz większa. Wydaje się, że są one w stanie kształtować społeczne nastroje i wpływać na podejmowane decyzje wyborcze. Etykietki nadawane politykom nie pozostają bez znaczenia dla rozwoju ich kariery. Chyba jednak dość trudno wpływać na szerzenie tych treści i podejmować próbę ich modyfikacji. Łatwość i szybkość przetwarzania memów zmienia bowiem nierzadko w jednej chwili obiekt krytyki i ogólną wymowę, sprawiając, że próby ingerencji w memetyczny przekaz stają się całkowicie nieskuteczne.

\section{Bibliografia}

\section{Źródta}

Bieńkowska o klopotach na PKP (2014), http://fakty.tvn24.pl/fakty-po-faktach,57/2001-bienkowska-o-klopotach-na-pkp-sorry-taki-klimat,389600.html, [dostęp: 11 czerwca 2015].

Latkowski Seweryn, Majewski Michał, Cezary Bielakowski i in. (2014), Afera podstuchowa, „Wprost”, nr 25, s. 14-24.

MK (2011), Komorowski łączy się ,,w bulu i nadzieji” z Japończykami, „Wprost”, 18 marca, http://www.wprost.pl/ar/236287/Komorowski-laczy-sie-w-bulu-i-nadziejiz-Japonczykami/, [dostęp: 12 marca 2015].

„Nas nie przekonaja, że białe jest białe, a czarne jest czarne!” (2015), http://www. polskieradio.pl/121/2083?xID=11, [dostęp: 7 lutego 2016].

Wpis prezydenta Bronisława Komorowskiego do księgi kondolencyjnej (2015), http:// wiadomosci.gazeta.pl/wiadomosci/51,114873,9276620.html?order=najnowsze, [dostęp: 11 czerwca 2015].

\section{Literatura}

Conte Rosaria (2000), Memes through (social) minds, w: Darwinizing culture: The status of memetics as a science, ed. Rosaria Aunger, Oxford, s. 83-120. 
Kamińska Magdalena (2011), Uwaga, zaraźliwe memy! Perypetie znaku w Internecie, w: tejże, Niecne memy. Dwanaście wykładów o kulturze Internetu, Galeria Miejska „Arsenał”, Poznań, s. 57-73.

Kochan Marek (1994), ,Przyklejanie etykietek”, czyli o negatywnym określaniu przeciwnika, w: Język polityki a współczesna kultura polityczna, t. 11, red. Janusz Anusiewicz, Bogdan Siciński, Towarzystwo Przyjaciół Polonistyki Wrocławskiej, Wrocław, s. 85-90.

Kosedowski Marcin (2015), Trzy fakty o marketingu, którymi zaskoczysz znajomych, http://like-a-geek.pl/marketing/3-rzeczy-ktorych-mozesz-nie-wiedziec-omarketingu/, [dostęp: 6 lutego 2016].

Krasowska Anna (2013), Od Zielonego Balonika do Potem. Komizm słowny w kabarecie literackim, Wydawnictwo Uniwersytetu Kardynała Stefana Wyszyńskiego, Warszawa.

Niekrewicz Agnieszka (2013), Kot jako bohater memów internetowych: między gra językową a diagnozą rzeczywistości, w: Kot w kulturach świata, red. Elżbieta Skorupska-Raczyńska, Joanna Rutkowska, Wojciech Kuska, Wydawnictwo Naukowe Państwowej Wyższej Szkoły Zawodowej im. Jakuba z Paradyża w Gorzowie Wielkopolskim, Gorzów Wielkopolski, s. 157-169.

Niekrewicz Agnieszka (2015), Od schematyzmu do kreacyjności. Język w memach internetowych, Wydawnictwo Naukowe Państwowej Wyższej Szkoły Zawodowej im. Jakuba z Paradyża w Gorzowie Wielkopolskim, Gorzów Wielkopolski.

Walkiewicz Adam (2012), Czym sa memy internetowe? Rozważania z perspektywy memetycznej, ,Teksty z Ulicy”, nr 14, s. 47-69.

Agnieszka Anna Niekrewicz

\section{Linguistic and illustrative measures used for labelling politicians in Internet memes}

This article presents techniques for creating a negative image of a party and their representatives in Internet memes. The author indicates the typical for memes linguistic measures used for depreciation of individual politicians and at the same time contributing to the perpetuation of their axiologically unequivocal image, usually based on a single exaggerated feature. The author analyses examples of repetitions of lapses committed by politicians, key words that characterize them according to memetic scheme, descriptive and evaluative names replacing the names, verbal jokes based on polysemy and homonymy as well as spelling innovation.

KEYwords: Internet meme; language valuation; stereotype. 
dr hab. Agnieszka Anna Niekrewicz - Zakład Języka Polskiego, Państwowa Wyższa Szkoła Zawodowa im. Jakuba z Paradyża w Gorzowie Wielkopolskim; zainteresowania naukowe: dziedzictwo leksykalne staropolszczyzny, leksykologia, pragmalingwistyka, językoznawstwo kulturowe, język memów internetowych. 